This PDF is a selection from an out-of-print volume from the National Bureau of Economic Research

Volume Title: The Postwar Rise of Mortgage Companies

Volume Author/Editor: Saul B. Klaman

Volume Publisher: NBER

Volume ISBN: 0-87014-374-3

Volume URL: http://www.nber.org/books/klam59-1

Publication Date: 1959

Chapter Title: Introduction and Historical Sketch

Chapter Author: Saul B. Klaman

Chapter URL: http://www.nber.org/chapters/c2554

Chapter pages in book: (p. 1 - 7) 


\section{INTRODUCTION AND HISTORICAL SKETCH}

The modern mortgage company is typically a closely held, private corporation whose principal activity is originating and servicing residential mortgage loans for institutional investors. It is subject to a minimum degree of federal or state supervision, has a comparatively small capital investment relative to its volume of business, and relies largely on commercial bank credit to finance its operations and mortgage inventory. Such inventory is usually held only for a short interim between closing mortgage loans and their delivery to ultimate investors.

More than any other type of institution active in mortgage markets, mortgage companies owe their present structure and method of operation, as well as their extraordinarily rapid postwar growth, to the introduction and later expansion of federal mortgage insurance and guaranty. The Federal Housing Administration and Veterans Administration mortgage underwriting programs, with their standardized mortgage contracts, uniform and improved property and borrower appaisal techniques, and minimization of risk, have reduced geographic barriers to mortgage investment and enhanced negotiability of contracts. In the broadened national mortgage market that developed, accompanying the marked postwar expansion in residential building and financing, mortgage companies grew rapidly in response to the increased need by out-of-state investors for local institutions to originate and service mortgages.

In its postwar operations and growth the mortgage company, differing radically from its early predecessors, has played an increasingly important role in the changing institutional framework of mortgage and construction markets. It has been closely associated with the development of new market techniques and characteristics during periods of credit ease and stringency. It has provided a bridge between primary and secondary mortgage markets and a channel for the flow of both short- and long-term funds, often from capital surplus to capital deficit areas. The mortgage company has been a key factor in the expanded use of short-term bank credit in mortgage operations, as it has adapted its operations to new commitment and lending techniques and used such credit more intensively to supplement long-term funds in periods of capital market stringency. 
Despite the integral and uniquely important role of mortgage companies in postwar mortgage markets, very little quantitative or qualitative information has been available on their background and development, on their financial structure, or on the nature of mortgage operations. Analysis of mortgage market developments, current and past, has been seriously hampered by this lack of information. This study, therefore, represents an attempt to fill the gap in knowledge about a rising new institution on the capital market scene.

The story of the origin and development of specialized mortgage banking in the United States is, to my knowledge, nowhere adequately documented and must be deduced from a few scattered writings and from direct interviews with individuals who have accumulated wide knowledge and experience in industry operations ranging over several decades. ${ }^{1}$ From these sources, it appears that companies organized specifically to lend on mortgages or to arrange mortgage financing were in active operation during part of the eighteenth century and in the nineteenth. Operations of many of these companies, however, were distinctly different from those of mortgage companies organized in the twentieth century, most of which now in operation have a continuous history reaching back only to 1930. Nevertheless, there is a clear relationship between yesterday's and today's mortgage companies, and the connection can be traced as an evolutionary development.

Reflecting the early history of the nation, the first specialized mortgage banking institutions were organized to meet the needs for credit to finance land settlement and improvement. As far back as the beginning of the eighteenth century, land banks established to make loans on real estate financed their operations by issuing notes secured by real estate mortgages. ${ }^{2}$ These early land banks had short histories because of mismanagement and speculation, but the idea was pursued in the early part of the nineteenth century by "the development in the southern states of property banks, which were mainly associations of borrowers subscribing mortgages on land for capital stock and making loans from funds obtained by the sale of bonds secured by mortgages and guaranteed by the states. Between 1840 and 1850 a regular farm mortgage banking business devel-

1 Interviews and informal discussions were held with mortgage company officials and other experts either associated or acquainted with companies located in Washington, D. C., Philadelphia, Cleveland, Chicago, Dallas, Los Angeles, various cities in New Jersey and several other states. In addition, an early draft of the manuscript was reviewed by executives of several mortgage and life insurance companies and bank officers, whose comments were used as a basis for revisions in portions of this section.

'Miles L. Colean, The Impact of Government on Real Estate Finance in the United States, National Bureau of Economic Research, New York, 1950, p. 57. 
oped in the Middle West ... [but] the tendency to finance on the basis of anticipated land values brought widespread failure."3

Mortgage loan companies continued to be organized after 1850 chiefly in the agricultural areas of the nation. Of 167 companies operating in 1891, more than half were concentrated in the three states of Kansas, Nebraska, and Missouri, and most of the remainder were in Iowa, the Dakotas, Minnesota, and Colorado. ${ }^{4}$ Many of these companies operated as mortgage banks, issuing debenture bonds to the public to finance their real estate mortgage lending, as the earlier land banks did in this country, and as European mortgage banks did and still do. In a combined balance sheet of 65 mortgage loan companies for 1893 , assets of $\$ 72$ million in first and second mortgage loans were nearly offset by $\$ 63$ million in outstanding debentures. The remaining mortgages were financed from paid-in capital. ${ }^{5}$ In addition to their mortgage lending operations, some of the companies carried on a general banking business as well, "about one-half the deposits being represented by loans on personal and collateral security, and the other half by stocks and bonds." 6

A significant proportion of mortgage companies doing business around the turn of the century operated by originating mortgages for direct sale to investors rather than by issuing debentures secured by mortgages as did the mortgage banks. Sales were made "over-the-counter" mainly to individuals and included mortgages with principal and interest both guaranteed and unguaranteed. These mortgage companies financed their operations with their own capital supplemented by bank loans secured by mortgages, much as present-day mortgage companies do. In the earlier period, the ratio of capital invested by companies to their mortgage loans closed, while small, was apparently somewhat larger than is now common. This is explained by the differing basis for originating mortgages, many earlier companies acting on their own financial responsibility and most presentday companies on the basis of institutional investor commitments.

On urban properties, typical loans made by mortgage companies, as well as by most other originators, called for a three-year repayment period on an unamortized basis. At least one renewal was common for most mortgages. For originating such loans, usually to residential builders, mortgage companies received fees ranging from one to two per cent of

3Ibid. p. 58. Sources of quoted statements are cited by Colean.

4D. M. Frederiksen, "Mortgage Banking in America," Journal of Political Economy, March 1894 , p. 213. For a description and discussion of the location of modern mortgage companies, see this paper, Tables 6, 7, appendix Tables A-13 and A-14. and the last pages of section 3 .

5Frederiksen, op. cit., p. 212.

Blbid., p. 215. 
the amount of the loan, depending on the tone of the market. In addition, companies might earn renewal fees (one per cent) on mortgages renewed at the expiration of the three-year contracts, and also the interest paid on loans prior to their sale to ultimate investors. Because mortgage loans were not amortized, and tax and insurance payments were not escrowed, the little servicing required, chiefly collection and forwarding of interest payments to investors, was done by mortgage companies at no charge to investors. Sale of these loans to private individuals at no charge permitted the investors to earn the entire gross interest on mortgages. Both whole loans and shares in loans were sold to individuals, as evidenced by notes in varying but ordinarily small amounts.

While guaranteed mortgages were sold by these companies, the proportion was fairly modest compared to their total operations. During the real estate boom of the twenties another type of mortgage banking house came into prominence, known generally as the mortgage guarantee company. These companies operated principally by originating mortgages, usually on large-scale income properties, and selling (1) whole mortgages to institutional investors or (2) mortgage participation bonds to individual investors; guaranteeing the principal and interest of each type of investment. Generally, on mortgage bonds bearing a contract interest rate of 6 per cent the companies undertook to guarantee a minimum return of 4.5 per cent, charging a fee of 0.5 per cent for guarantee and services. The invested capital in most of these companies was very small compared to the amount of their outstanding guarantees, and the speculative practices of the era led to widespread inept and often illegal practices. Most mortgage guarantee companies were unable to honor their commitments in the subsequent real estate collapse of the thirties and were forced into receivership. ${ }^{7}$ Several of today's mortgage companies are reorganizations of bankrupt mortgage guarantee companies of the twenties, most of which were not resurrected.

Among the early types of mortgage specialists preceding the presentday mortgage companies was the mortgage brokerage house. In the late nineteenth century and early twentieth, farm mortgage brokers were a

7 Very few mortgage guarantee companies managed to survive the debacle. One such company, now one of the largest mortgage companies in the country, found itself with $\$ 18$ million in outstanding mortgage guarantees and $\$ 4$ million in capital in 1929. Most of its guarantees, however, were to institutional investors who, upon appeal, agreed to release the company from its obligations in return for continued servicing of mortgages, handling of all necessary foreclosures, and management and rehabilitation of foreclosed real estate. Released from its major obligation to institutions, the company was able to meet its guarantees to individual bond holders, kept its doors open throughout the depression, and went on to reorganize the structure of its operations to become one of the most successful of mortgage originators and servicers. 
dominant element in the mortgage banking business. This was reflected in their preponderance in the membership of the Mortgage Bankers Association when it was organized in 1914. Many of these brokerage houses were organized as farm mortgage correspondents by life insurance companies when the latter were investing heavily in farm mortgages before the 1930's. This arrangement served as a pattern for urban mortgage correspondent relationships in later years when many firms expanded into urban mortgage brokerage as the country became more industrialized, and gradually encompassed mortgage banking or merchandising operations.

To recapitulate, mortgage banking, in its various stages of development before 1930, was carried on by four distinct types of institutions and operations:

1. Mortgage banks originating mortgages and issuing to the public their own obligations secured by these mortgages

2. Mortgage guarantee companies originating mortgages and selling them and mortgage bonds, guaranteed for principal and interest, to institutions and individuals

3. Mortgage loan companies originating and selling mortgages directly to investors

4. Mortgage brokers arranging transactions between borrowers and lenders without direct ownership of the mortgages

For all types of organization, the chief investor in mortgages was the individual. In the legal sense three parties had an interest in types 1 and 2, and two in types 3 and 4 . Both the mortgage bank and mortgage guarantee company had direct obligations to the general public, either through debentures or guarantees, in addition to their relation to mortgage borrowers and lenders. Neither the mortgage loan company nor the broker, on the other hand, had direct obligations outstanding to anyone as a result of the transactions each arranged.

Introduction of the FHA mortgage insurance program in 1934 in the midst of the depression set the stage for the appearance of the modern mortgage company, its further growth being sharply stimulated by the VA mortgage guarantee program established in 1944. These federal programs, providing for the underwriting of mortgages on very liberal terms to borrowers, minimizing risk to lenders and facilitating mortgage arrangements for builders, were basic to the accelerated postwar demand for home mortgage loans, to the flow of funds from institutional investors across state borders, and to the growth of large-scale home builders and mass merchandising programs. The profitable and specialized task of arranging for and channeling the flow of mortgage funds from investors 
to merchant builders and ultimately to home purchasers became the province of the mortgage company, and the process entailed marked changes in its structure and methods of operation.

Among institutional investors, life insurance companies, legally least bound to local investments, became strongly attracted to a national mortgage investment program. For most of these companies, the problem of acquiring and servicing out-of-state mortgage investments was resolved by appointment of locally owned and operated mortgage correspondents rather than by establishment of branch offices or subsidiaries of the parent company. The mortgage banking industry undoubtedly owes a large part of its growth and character to this basic decision of the life insurance companies. Later, when legal barriers to out-of-state investments in FHA and VA loans were removed for other institutions, the pattern of mortgage acquisition established by insurance companies was followed, particularly by many mutual savings banks.

Because, at the beginning of the federal mortgage insurance program in the early thirties, there were few mortgage companies relative to the increased demand for their services, the life insurance companies selected as mortgage correspondents real estate companies, brokers, attorneys, and others connected with the real estate industry. Thus many of today's mortgage companies have predecessors that operated for a shorter or longer period in one or another phase of the real estate business. The few pre-FHA mortgage companies shifted the focus of their activity from individuals to institutional investors because individuals are not permitted to hold FHA-insured mortgages, and the long-term amortized mortgage is not well suited to their investment needs. This development was described by an old-line mortgage company as follows:

From its beginning in 1896 to along about 1935 or 1936, all the mortgages made by our company were sold to the individual investor.

... We did not discontinue such business on account of the few depression years, but rather because with the advent of the HOLC and FHA, a new pattern for mortgage lending was established, via the long-term monthly level payment loan, and although popular with the borrower and most lending institutions, it was not so with the individual investor. Experience taught us that the average individual investor did not like to buy a long-term mortgage note, $\ldots$ and he did not like small partial payments coming back to him all the time.

While we are still doing some individual mortgage business, it is for the most part a carry over from former years and we are not anticipating anything substantial as far as the individual investor goes in the immediate future. ${ }^{8}$

8Taken from a letter written by a New England mortgage banker and quoted in Mortgage Banking, by Robert H. Pease and Homer V. Cherrington, McGraw-Hill, 1953, pages 294-295. 
Thus, the FHA mortgage insurance and VA guaranty programs and the widespread adoption of the long-term amortized mortgage materially altered the organization and structure of the mortgage banking industry. At one and the same time the new type of mortgage instrument attracted large-scale institutional investors to a national mortgage market and discouraged the participation of individual investors. Many mortgage companies, formerly engaged in initiating mortgage transactions largely on their own responsibility for sale to individuals, became the direct representatives of institutional investors in local markets. The bulk of the business of most mortgage companies shifted from conventional residential and nonresidential mortgages, in the pre-federal underwriting days, to federally underwritten home mortgages. Finally, a new type of profitable activity - mortgage servicing - required by the monthly amortization of mortgages and the escrow of funds for tax and insurance payments became the source of the basic and generally largest component of net income of mortgage companies. 